\title{
Evaluation of Plankton Community Structure in Fish Refugia Acting as Oreochromic niloticus Propagation and Nursery Units for Rice/Fish Trials, Uganda
}

Grace A Ssanyu ${ }^{1 *}$, Joseph Rasowo ${ }^{2}$, Elmada Auma ${ }^{3}$ and Moses Ndunguru ${ }^{4}$

${ }^{1}$ Department of Biological Sciences, Kyambogo University, Box 1 Kyambogo, Uganda

${ }^{2}$ Department of Biological Science, Moi University, Box 1125 Eldoret, Kenya

${ }^{3}$ Department of Seed, Crop and Horticultural Sciences, Moi University, Box 1125 Eldoret, Kenya

${ }^{4}$ Institute of Development Studies, Mzumbe University, Box 83 Mzumbe, Tanzania

\begin{abstract}
To determine the possible success or failure of the propagation system, plankton species diversity and biomass were investigated for 98 days in relation to fish fingerling numbers produced from the fish refugia along rice paddies. The experiment was laid out in a split-plot design, with a rice variety (Kairo 25) as the main plot and method of rice-fish culture (fish refugia) as the sub-plot. The fish refugia were propagating Tilapia fish (Oreochromis niloticus) and were manure only once at the beginning. The results showed that the level of nutrients (nitrate-nitrogen and orthophosphate) was low during the growing season limiting the phytoplankton wet biomass. However, a diverse phytoplankton community was realised with Euglenophyta having the higher number of species followed by Chlorophyta, Cyanobacteria, Bacillariophyceae, Dinophya and Cryptophyta. Among the zooplankton, rotifers were more common than crustaceans. Bachiomonus sp Keliyota sp and Asplanchina sp were the most dominant rotifers while Moina and Cyclopoids were also the commonest crustaceans in the refugia. A high number of fish fingerlings harvested every two weeks from each refugia. The fish refugia (paddy 2) that recorded higher numbers of large sized phytoplankton (Euglenoids and Dinoflagellates), had a higher number of large sized fingerlings harvested. This was attributed to the selective feeding of the fingerlings for smaller zooplankton leaving large size zooplankton that effectively feeds on smaller phytoplankton. It was realised that fish refugia are favourable for propagating and raising tilapia fry due to the presence of a good plankton community. Regular manuring of the fish refugia is envisaged to maintain better plankton community for higher fingerling yield in the rice paddies.
\end{abstract}

Keywords: Tilapia; Fry culture; Phytoplankton; Zooplankton; Fish refugia; Rice paddies

\section{Introduction}

Fish supply in many developing countries is less than $10 \%$ of the estimated requirement of $35 \mathrm{~g}$ per capital per day and yet demand by 2010 for these countries is increasing [1]. In the late 1980s, global interest in rice-fish farming was renewed [2] mainly to meet the challenge of the increasing demand for fish. Such small-scale fishery can both provide nutritional security in remote areas that lack adequate supplies of animal protein and sustain the livelihood of landless fishers who can no longer survive by fishing in depleted rivers and other natural freshwater bodies [3]. Paddy-fish systems are low cost effective and bring about economic returns [4]. These small-scale fishery trials have been limited to a few countries in Africa, mainly in West Africa and yet they offer the advantage of producing two crops from the same piece of land.

Most irrigated rice fields are usually successors of shallow marshes or a lowland area that can be supplied with adequate water [5]. They are temporary and seasonal aquatic habitats, managed with a variable degree of intensity [6]. Fishes are an integral part of these rice fields especially in the tropics [7]. Therefore, presence of permanently standing bodies of water in a large number of valleys makes the East African region well suited for rice/fish farming. However, a large working capital needs to be mobilised to buy fish feed and fingerlings, resulting in over dependent farmers on uncertain supply systems. According to Simon and Benhamou [8] the extensive propagation strategies are seen as more suitable for local context in which the fish are fed free of charge in farmers' own fields.

In the culture of larval fish of various species, the management of zooplankton and phytoplankton is very important for successful transition of larvae to the fingerling stage [9]. The relative status of plankton (zooplankton and phytoplankton) community structure gives an indicator of the water quality parameter and the possible success of failure of the culture system. Through the addition of fertilizer or manure, water quality is manipulated to enable successful colonization and abundance of plankton communities. This avails proper nourishment for larval fish till fingerlings stage for stocking in grow out ponds or rice paddies. Fry behaviour still seems to indicate reliance on natural food organisms during the first 3-4 weeks of culture and there is no evidence available that fry actually consume prepared feeds added to the ponds during the initial weeks of culture [10]. High concentrations of copepods, cladocerans and ostracods would be desirable from the time of stocking through about 5 weeks of production. Direct relationships between fish ingestion rates, larval size, or fish larval density to prey density appear to exist [11]. Zooplankton react quickly to changes in

${ }^{*}$ Corresponding author: Grace A Ssanyu, Department of Biological Sciences, Kyambogo University, P.O Box 1, Kyambogo, Tel: +256 712 186840; E-mail: ssangrace@mail.com

Received August 20, 2011; Accepted October 18, 2011; Published October 22, 2011

Citation: Ssanyu GA, Rasowo J, Auma E, Ndunguru M (2011) Evaluation of Plankton Community Structure in Fish Refugia Acting as Oreochromic niloticus Propagation and Nursery Units for Rice/Fish Trials, Uganda. J Aquac Res Development 2:116 doi:10.4172/2155-9546.1000116

Copyright: (C) 2011 Ssanyu GA. This is an open-access article distributed under the terms of the Creative Commons Attribution License, which permits unrestricted use, distribution, and reproduction in any medium, provided the original author and source are credited. 
Citation: Ssanyu GA, Rasowo J, Auma E, Ndunguru M (2011) Evaluation of Plankton Community Structure in Fish Refugia Acting as Oreochromic niloticus Propagation and Nursery Units for Rice/Fish Trials, Uganda. J Aquac Res Development 2:116 doi:10.4172/2155-9546.1000116

Page 2 of 6

\begin{tabular}{|c|c|c|c|c|c|c|c|}
\hline Rice paddies & Temperature $\left({ }^{\circ} \mathrm{C}\right)$ & Dissolved oxygen $\left(\mu \mathrm{gl}^{-1}\right)$ & $\mathrm{pH}$ & $\mathrm{NH}_{4}-\mathrm{N}\left(\mu \mathrm{gl}^{-1}\right)$ & $\mathrm{NO}_{3}-\mathrm{N}\left(\mu \mathrm{gl}^{-1}\right)$ & $\mathrm{PO}_{4}-\mathrm{P}\left(\mu \mathrm{gl}^{-1}\right)$ & Water depth (m) \\
\hline Paddy 1 & $25.4 \pm 0.81^{a}$ & $10.02 \pm 1.14^{a}$ & $6.9 \pm 0.22^{a}$ & $<0.1^{\mathrm{a}}$ & $1.33 \pm 0.52$ & $<0.5^{\mathrm{a}}$ & 0.75 \\
\hline Paddy 2 & $24.8 \pm 0.73^{a}$ & $9.3 \pm 1.16^{\mathrm{a}}$ & $7 \pm 0.10^{a}$ & $<0.1^{\mathrm{a}}$ & $1.5 \pm 0.55$ & $<0.5^{\mathrm{a}}$ & 0.8 \\
\hline Paddy 3 & $25.5 \pm 0.92^{\mathrm{a}}$ & $10.64 \pm 0.52^{b}$ & $7.2 \pm 0.3^{a}$ & $<0.1^{\mathrm{a}}$ & $1.5 \pm 0.54$ & $<0.5^{\mathrm{a}}$ & 0.52 \\
\hline Paddy 4 & $25.6 \pm 0.71^{a}$ & $9.02 \pm 0.86^{b}$ & $6.9 \pm 0.23^{a}$ & $<0.1^{\mathrm{a}}$ & $1.5 \pm 0.55^{\mathrm{a}}$ & $<0.5^{\mathrm{a}}$ & 0.65 \\
\hline
\end{tabular}

Where values with a were not significantly different and those with $b$ were significantly different at $p=0.05$.

Table 1: Mean values of the water parameters of the fish refugia in the rice paddies from 12 March to 9 August 2009.

\begin{tabular}{|l|l|l|l|l|}
\hline \multicolumn{1}{|c|}{ Taxa } & \multicolumn{1}{c|}{ Paddy 1 } & \multicolumn{1}{c|}{ Paddy 2 } & \multicolumn{1}{c|}{ Paddy 4 } \\
\hline Blue greens & $3431.85 \pm 925^{\mathrm{b}}$ & $3698.99 \pm 950^{\mathrm{c}, \mathrm{d}}$ & $2088.95 \pm 625^{\mathrm{c}}$ & $5237.16 \pm 1147^{\mathrm{b}, \mathrm{d}}$ \\
\hline Diatoms & $937.17 \pm 263^{\mathrm{b}, \mathrm{c}}$ & $607.93 \pm 164^{\mathrm{b}, \mathrm{d}}$ & $700.12 \pm 139^{\mathrm{a}}$ \\
\hline Greens & $4319.58 \pm 2411^{\mathrm{b}}$ & $5756.78 \pm 2411^{\mathrm{c}}$ & $978.86 \pm 228^{\mathrm{b}, \mathrm{c}}$ \\
\hline Euglenophytes & $9435.12 \pm 1816^{\mathrm{a}}$ & $5829.07 \pm 1540^{\mathrm{a}}$ & $4386.38 \pm 1621^{\mathrm{a}}$ & $331.63 \pm 114^{\mathrm{c}, \mathrm{d}}$ \\
\hline Dianoflagellates & $4692.60 \pm 1654^{\mathrm{b}}$ & $4500.29 \pm 1654^{\mathrm{c}}$ & $3488.51 \pm 1633^{\mathrm{d}}$ & $3247.16 \pm 1574^{\mathrm{a}}$ \\
\hline Cryptophytes & $33.50 \pm 0.31^{\mathrm{b}}$ & $1.7 \pm 0.2^{\mathrm{c}}$ & $167.27 \pm 87^{\mathrm{b}, \mathrm{c}, \mathrm{d}}$ & $982.26 \pm 207^{\mathrm{b}, \mathrm{c}, \mathrm{d}}$ \\
\hline
\end{tabular}

Where the values with same letter were significantly different and those with a were not significantly different in the same row.

Table 2: Average wet biomass ( $\mu \mathrm{gl}-1)$ of the major phytoplankton taxa of the fish refugia from 12 March to 9 August 2009.

prey and predator abundance [12]. Zooplankton feed mainly on the small algae (1-25 um) mainly the blue green algae [13]. Therefore, the best environmental condition for raising fry would be one that quickly establishes a phytoplankton bloom to produce the greatest number of large zooplankton at the time of fry growing.

In order to refine rice-fish farming, there is a thrust of improving fish production without affecting rice production. Among the identified possible areas and topics for research for various countries is the development of rice field hatchery and/or nursery system, vacant food niches, present combination of fish species and nutrient status. These will determine how best to manage the fishery and enhance its yield in a phased manner. The purpose of the present research was to test a 'low-tech' method for propagating Tilapia fish for rice-fish systems. This paper evaluates the use of rice paddies as propagation and nursery ponds for Oreochromis nilotics based on the plankton community composition. This was geared towards promoting the use of rice paddies for propagating fish and increase fish fingerling availability to rice-fish integrated systems in East Africa.

\section{Materials and Methods}

\section{Study area}

The study was carried out a rice fish integrated farm in Iganga district (33o 04' east and 00o 37' north) which is about $110 \mathrm{Km}$ from Kampala. The climate is tropical with two relatively drier seasons between December to March and June to July. A mean annual rainfall of $1200 \mathrm{~mm}$ in the western south and $900 \mathrm{~mm}$ in the drier northern west is experienced. The relatively flat area favours rice growing at both large and small scale levels with in the wetlands which cover $30 \%$ of the district geographical area. The most outstanding environmental issue regarding the district is the extensive drainage of wetlands for agricultural expansion; $64 \%$ of the total seasonal wetlands have been reclaimed for rice and sugar cane production [14].

\section{Sampling design}

The experiment was laid out in a split-plot design, with rice cultivar (K25) as the main plot and method of rice-fish culture (fish refugia) as the sub-plot, during the rice growing season of 05 March to 19 August 2009. Four rice paddies (each $10 \times 3 \mathrm{~m}$ ) were modified to accommodate both rice growing, fish propagation and nurseries. $10 \%$ of each rice paddy was modified by manually excavating peripheral fish refugia about $1 \mathrm{~m}$ wide and $1 \mathrm{~m}$ deep. The size rice alone was $5 \times 3 \mathrm{~m}$, rice/fish integration $3 \times 3 \mathrm{~m}$ and the fish refugia was $2 \times 3 \mathrm{~m}$. Dikes were raised and screens installed in water gates to prevent escape of fish.

Each fish refugium was covered with $3 \mathrm{~kg}$ of lime and was left to stand for 3 days before filling them with water. The refugia were fertilized using chicken manure at $1000 \mathrm{~kg} / \mathrm{ha}$ (about $3 \mathrm{~kg}$ per refugia) once for the whole rice growing season. No inorganic fertilizers were put in the refugia. Water quality parameters were measured before and after stocking the fish. Dissolved oxygen, nitrate nitrogen ammonia and $\mathrm{pH}$ were measure using Lamotte testing kits. Phytoplankton was collected in 0.5 litre canister from a $0.2 \mathrm{~m}$ depth and preserved using Lugol's solution. Phytoplankton counts and length measurements were done using a light microscope. Using the total counts, length and biovolume formula each taxa biomass was calculated. Algae identification keys up to the genus or species levels where possible, using identification keys of Bourrelly [15], Coesel [16] and John et al. [17].

Zooplankton sampling was done using an integrated water sample collected with a 2 liter canister from the paddies and nearby fish pond for comparison. The fish was more than two year old working as propagation pond, nursery and grow out pond with stocked with both

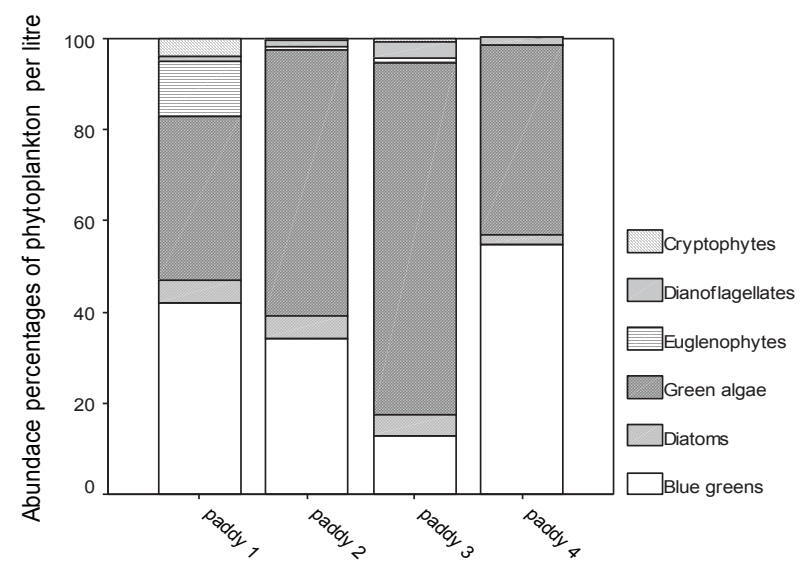

Fish refugia

Figure 1: Abundance of the major phytoplankton taxa in fish refugia from 12 March to 9 August 2009. 


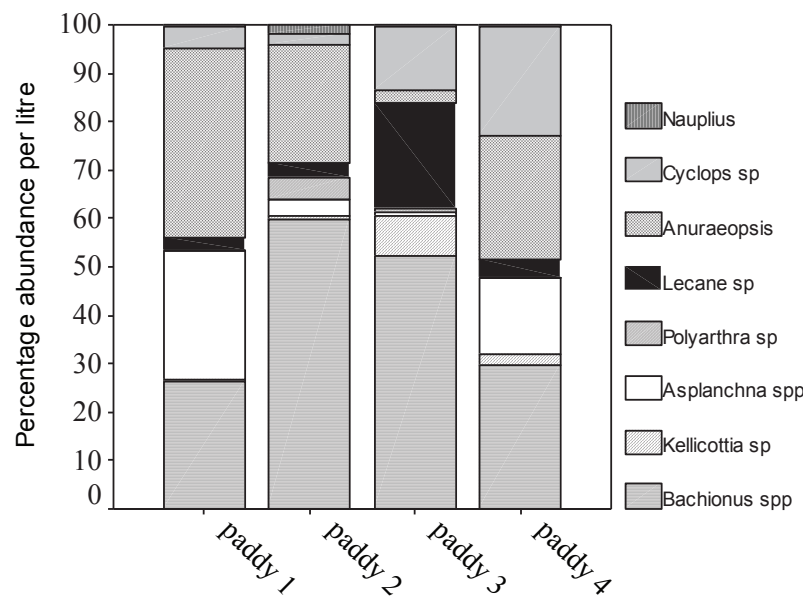

Fish refugia

Figure 2: Abundance percentages of dominant zooplankton in the fish refugia from 12 March to 9 August 2009.

Oreochromic niloticus and Clarias gariepinus. Water was filtered through a net of $5 \mathrm{~mm}$ mesh size and collected samples were preserved with $95 \%$ alcohol. Zooplankton counts were done using a light microscope. For large zooplankton like Brachiomonus species which occurs at relatively low densities (1-100 per litre), the entire sample was scanned at low magnification and small zooplankton which occur higher densities $(>$ 1000 per liter) such as rotifers and copepod nauplii, a counting chamber was used at a higher magnification.

Brooders of Nile tilapia (Oreochromis niloticus) were procured from the National Agricultural Research Organisation Kajjansi and stocked in the pond refugias. The fish refugia were stocked with broad fish at a ratio of 3:1; female: male fish, 4 weeks after rice transplanting [18]. The brood fish were fed with Ugackick fish growers' meal at a rate of $3 \%$ the body weight per day. Schooling fingerlings were harvest by reducing to refugia water to one third and seining through the fish refugia using 5 $\mathrm{m}$ by $2 \mathrm{~m}$ ( $8 \mathrm{~mm}$ mesh) net fortnightly, to increase space for younger and newer frys nourishment. They were transferred directly into the nearby fish pond and rice paddies. Therefore, refugia were working both as propagation and nursery ponds.

The data was analysed by the SPSS 8.0 version for windows 10 licensed SPSS Inc. the mean values of the water parameters and their standard deviations were calculated and the differences between fish refugia were analysed using the one-way analysis of variance ANOVA, then later by LSD test at a significance level of $p<0.05$. Pearson correction was used to check for the presence of significant relationships between fingerling number and plankton numbers and biomass.

\section{Results}

The fish refugia/paddies had $\mathrm{pH}$ values within the favorable range for plankton growth, ranging between 6.5 and 8.5 (Table 1). The dissolved oxygen was also within the appropriate range for fish and fingerling growth, ranging between 7.8 and $11.2 \mathrm{ppm}$ at midday. The nutrients were very low with ammonia nitrogen $(\mathrm{NH} 4-\mathrm{N})$ below $0.1 \mathrm{ppm}$, nitrate-nitrogen $(\mathrm{NO} 3-\mathrm{N})$ between 0.5 and $2 \mathrm{ppm}$ and orthophosphate $\left(\mathrm{PO}_{4}-\mathrm{P}\right)$ below $0.5 \mathrm{ppm}$. There was no significant difference in the above parameters in the different fish refugia.

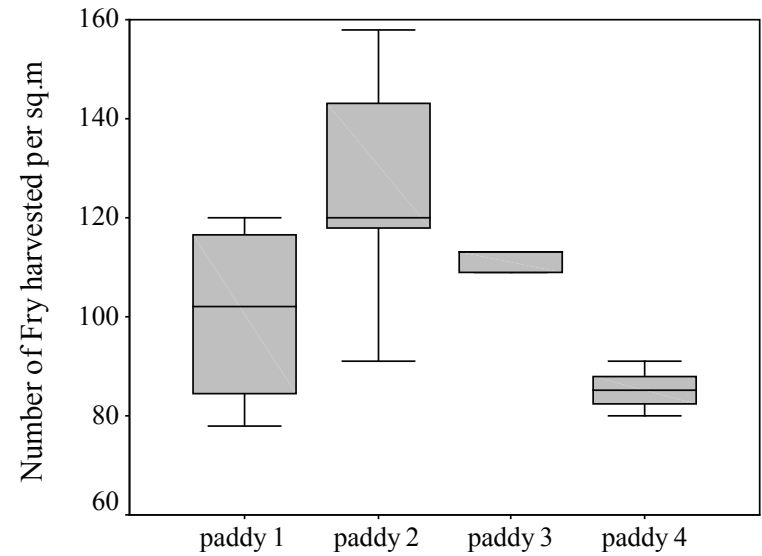

Fish refugia

Figure 3: The number of fingerlings harvested every two weeks during the rice growing season from 12 March to 9 August 2009.

\begin{tabular}{|r|c|c|}
\hline Fish refugia & Mean number of fingerlings per acre & Length of fingerlings $(\mathrm{mm})$ \\
\hline Paddy 1 & 58092 & $63.68 \pm 14.68$ \\
\hline Paddy 2 & 66040 & $71.44 \pm 9.34$ \\
\hline Paddy 3 & 62717 & $62.8 \pm 13.75$ \\
\hline Paddy 4 & 48988 & $60.04 \pm 15.98$ \\
\hline
\end{tabular}

Table 3: Mean number of tilapia fingerlings harvested fortnightly from the rice paddies from 12 March to 9 August 2009.

79 taxa of phytoplankton were identified in the fish refugia (Table 4). The highest number of taxa belonged to Euglenophyta [24], followed by Chlorophyta [17], Cyanobacteria [16], Bacillariophyceae [11], Dinophya [7] and Cryptophyta [4]. The algal biomass was also highest among the Euglenophyta, followed by Chlorophyta, Cyanobacteria, Bacillariophyceae, Dinophya and the least was the Cryptophyta (Table 2). Green algae recorded higher total counts than other taxa with a range of $3.27 \times 10^{6}$ to $5.87 \times 10^{7}$ and Cryptophyta had the lowest counts in all the paddies, with a range of $2.7 \times 10^{5}$ in paddy 2 and $3.45 \times 10^{6}$ in paddy 1(Figure 1). There was a significant difference in algal biomass between green algae in paddy 1 and 4 at $p=0.024$, paddy 2 and 3 at $p=0.000$ and paddy 2 and 4 at $\mathrm{p}=0.039$. There were also significant differences in Euglenophyte and other taxa biomass between paddies as shown in table 2 at $\mathrm{p}<0.05$.

13 taxa of zooplankton were recorded in the fish refugia. There was variation in abundance of the dominant taxa as shown in figure 2. Comparing the newly dug fish refugia and a 10-year old fish pond, the fish ponds had only 7 taxa zooplankton. Brachiomus sp, Killicotia sp, Anuraeapsis sp, Moina sp and Cyclopoids sp were common in both fish refugia and fish pond. However the refugia had a higher number of individuals of these taxa. The number of Moina ranged from 130 to 1190 individuals per litre in the refugia while in the fish pond it was 435 individuals per litre on average. Even the Brachionus sp were higher in the fish refugia with a mean value of 2697 individuals per litre in paddy 2 as compared to a mean of 65 individuals per liter in the fish refugia. There was a significant difference between zooplankton numbers in the refugia and fishpond at $\mathrm{p}=0.003$. Asplanchna sp, Polyarthra sp and Lecane sp were only found in the refugia water and Diaphanosoma sp was common in the pond water. 
Citation: Ssanyu GA, Rasowo J, Auma E, Ndunguru M (2011) Evaluation of Plankton Community Structure in Fish Refugia Acting as Oreochromic niloticus Propagation and Nursery Units for Rice/Fish Trials, Uganda. J Aquac Res Development 2:116 doi:10.4172/2155-9546.1000116

\begin{tabular}{|c|c|}
\hline CYANOPHYCEAE & Cyclotella sp \\
\hline Anabaena circinalis & Diatoma sp \\
\hline Anabaena flos-aquae & Fragillaria $\mathrm{sp}$ \\
\hline Aphanocapsa sp & Nitzschia fonticola \\
\hline Chroococcus limnetica & Navicula radiosa \\
\hline Chroococcus sp & Nitzschia acicularis \\
\hline Cylindrospermopsis africana & Nitzschia sp \\
\hline Cynococystis sp & Peridinium sp \\
\hline Merismopedia tenuissima & Rhodophidium sp \\
\hline Microcystis flos-aquae & Rhopolodia sp \\
\hline Microcystis aeuroginosa & Synedra cunningtonii \\
\hline Microcystis sp & EUGLENOPHYCEAE \\
\hline Planktolyngbya circumcreta & Closterium acicularis \\
\hline Planktolyngbya limnetica & Colacium calvum \\
\hline Planktothrix sp & Crucigenia apiculata \\
\hline Pseudoanabaena sp & Euglena acus \\
\hline Romeria gracile & Euglena gracilis \\
\hline DINOPHYCEAE & Euglena haematodes \\
\hline Peridinium sp & Euglena hemichromata \\
\hline Peridinium cinctum & Euglena pisciformis \\
\hline Peridinium dumplex & Euglena saguinea \\
\hline Cyclostephanodiscus sp & Euglena sp \\
\hline Gymnodium mirabile & Phacus carvicuada \\
\hline Gymnodium sp & Phacus longicauda \\
\hline Glenodinium sanguineum & Phacus pleuronectes \\
\hline BACILLARIOPHYCEAE & Phacus seucicus \\
\hline Phacus sp & Crucigenia apiculata \\
\hline Strombomonas fluviatilis & Kirchneriella obesa \\
\hline Strombomonas sp & Kirchneriella sp \\
\hline Trachelomonas intermedia & Oocystis lacutris \\
\hline Trachelomonas planctonica & Petalomonas sp \\
\hline Trachelomonas abrupta & Scenedesmus acuminatus \\
\hline Trachelomonas hispida & Scenedesmus arcuatus \\
\hline Trachelomonas scarba & Scenedesmus quadricuda \\
\hline Trachelomonas sp & Scenedesmus sp \\
\hline Trachelomonas hexangulata & Tetradron tetras \\
\hline CHLOROPHYCEAE & Tetraedron trigonium \\
\hline Ankistrodesmus falcatus & CRYPTOPHYCEAE \\
\hline Ankistrodesmus setigera & Cryptomonas curvata \\
\hline Monoraphidium contartum & Cryptomonas sp \\
\hline Closterium acicularis & Rhodomonas ovalis \\
\hline Coelastrum cambirium & Rhodomonas sp \\
\hline
\end{tabular}

Table 4: List of phytoplankton species in the rice/fish paddy from 12 March to 9 August 2009.

The mean number of fingerlings harvested per two week from the $7 \mathrm{~m}^{2}$ refugia was $95 \pm 23,113 \pm 29,101 \pm 20$ and $83 \pm 16$ for paddy 1 , paddy 2 paddy 3 and paddy 4 respectively (Figure 3). A significant deference was realized between the number of fingerlings harvested from paddy 2 and 1 at $\mathrm{p}=0.019$, between paddy 2 and 4 at $\mathrm{p}=0.000$ and between paddy 3 and 4 at $\mathrm{p}=0.029$. After standardizing the number of fingerlings per $7 \mathrm{~m}^{2}$ to per acre, the number of tilapia fingerlings harvested every after two weeks ranged between 45094 and 91345 per acre (Table 4). The water levels raised in the fish refugia after the heavy rains of May 2009, leading to the escape of brood fish from paddy 3 and 4 into the other two refugia. During this time the lowest number of fry harvested from paddy 4 . The fingerling length ranged from $30-$ $90 \mathrm{~mm}$ from all fish refugia. In the fish ponds, fry numbers produced were monitored due to the presence of catfish which highly controls fry numbers.

\section{Discussion}

In general, the aquatic environment in the rice fields was characterized with fluctuations in temperature, $\mathrm{pH}$ and dissolved oxygen. The temperature was lower in deeper paddy with tall dense rice plants than in the shallow paddies with short sparsely growing rice plants and this attributed to shading effect of the rice canopy. The temperature was never a limiting factor to plankton community and fry growth. Boyd [19] noted that in tropical culture systems, temperature ranges between $24 \mathrm{oC}$ and $29 \mathrm{oC}$ which makes them productive. Diurnal fluctuations are often about $5{ }^{\circ} \mathrm{C}$ and decrease with increased density of the rice canopy [2]. The $\mathrm{pH}$ was to a large extent stable and according to Osuigwe et al. [1] this was attributed to more hydrogen ions that were autochthonous and not affected by any allochthonous inputs. The results conquer with the fact that rice fields are characterized by shallowness, great variation in turbidity as well as fluctuations in temperature, $\mathrm{pH}$ and dissolved oxygen [20].

The dissolved oxygen level was varying from paddy to paddy and this was attributed to the activity in the refugia. Fish refugia (paddy 1 and paddy 2) with higher dissolved oxygen had water continuously flowing through them and situated at the windy side of field, on top of having more broad stock fish. These increased water mixing and thus more oxygen dissolution into the refugia water. Fish perturbation of the soil can result in aeration of water and would have been responsible for the higher dissolved oxygen level observed in the paddies. Another source of DO in the water column was the photosynthetic activity of the aquatic plant biomass that can lead to super-saturation in the mid-afternoon. The other refugia (paddy 3 and 4) suffered flooding and bank damage after heavy rains, losing water and brood fish to the next refugia (paddy 2 and 1). Muddy water state continued for almost a month in these refugia. The high level deposition of silt and organic matter in rice plots utilize considerable amount of dissolved oxygen for decomposition [21]. However, the dissolved oxygen of the refugia were within the favourable range for fish production since there was no single moment when a value of DO was below 5 parts per million (ppm) beyond which living organism would be stressed.

The nitrate-nitrogen and phosphorus levels were low and this was attributed algal nutrient uptake and the continuous flow of water in and out of the paddies that could not allow internal demineralization. The scarcity of chicken dropping in the village and the high costs involved in importing it from other villages, resulted to manuring only once at the beginning of the experiment. This boasted the nutrients level that encouraged the initial growth of plankton community. The relative scarcity of nitrogen and SRP increased later during the growing season as the plankton community grew and fish propagation set in. Refugia that accumulated mud and organic matter from flooding recorded increase nitrate-nitrogen due to deminealisation of the organic matter.

The phytoplankton biomass was moderate in the fish refugia as compared to high levels in fish ponds. Most fertilized fish ponds with dirty green water have more than $242 \mathrm{mg} \mathrm{l}^{-1}$ of phytoplankton biomass [10], yet our refugia had only a range of 35 to $101.8 \mathrm{mgl}^{-1}$. Very low or high primary productivity and plankton density do not favour fish growth [3]. The phytoplankton biomass was attributed to the low nutrient content in the paddies. The paddies were manured at the beginning allowing initial multiplication of the algae to that moderate level. The refugia $\mathrm{pH}$ was slightly acidic and basic allowing the coexistence of various taxa of aglae at high abundance. According to Halwart and Gupta [2], acidic conditions favor chlorophytes (green algae) while alkaline condition fosters nitrogen-fixing cyanobacteria. 
On the other hand, selective feeding on the algae by zooplankton and fish fingerlings could also have suppressed some algal taxa and encourage growth of another. Fish refugia with highest number of fingerlings recorded fewer diatoms. Periphytic detrital aggregates of diatoms are usually the principal diet in the paddy field while filamentous and colonial algae (Anabaena sp. and Melosira sp.) occurring as periphytic epipelon are the main food in the pond [22]. Zooplanktonic species differ in their selective feeding patterns depending mainly on prey size. Cyanobacteria are inedible prey for most of them [23], only small colonies or dispersed cells of cyanobacteria can be ingested. This could explain the presence lower zooplankton abundance in rice paddies with high cyanobacteria abundance. Where zooplankton grazing rates are high, small edible algae tend to be suppressed and larger indigestible algae can become dominant. All the algal species suppressed by high zooplankton grazing in the refugia with few fish were small edible types, although no large grazer-resistant algae developed [24]. Periphytic detrital aggregate was the principal diet in the paddy field while filamentous and colonial algae (Anabaena sp. and Melosira sp.) occurring as periphytic epipelon were the main food in the pond [22]. Zooplankton was an insignificant dietary component in both habitats. Total phytoplankton density was higher in the pond than in the rice field, while zooplankton densities were higher in the rice field.

The zooplankton community structure in refugia was also determined by the fish presence. A community characterized by rotifers that dominate in density and number of species, copepods that dominate in terms of biomass and a very low abundance and diversity is probably largely influenced by fish predation [25]. The reservoirs dominated by omnivorous fishes show predominance of the small-bodied herbivorous cladocerans and low taxonomic richness of zooplankton. Zooplankton utilizes many different methods to escape capture [26]. Additionally, different levels of ornamentation have evidently evolved as predator defense mechanisms. The rotifer Brachionus calyciflorus populations develop various levels of posterolateral spines that decrease predation by another rotifer, Asplancha spp and fish larvae [27]. Drenner and McComas [28] concluded that the impact of predators upon zooplankton stocks varies with the zooplankter's ability to escape predation, as well as the degree of size selection of prey.

Larger-bodied zooplankton was very low in the fish refugia. This was due the preferential removal by fish, leading to a selective pressure for smaller-bodied populations. Increased predation by planktivorous fish on larger zooplankton such as Daphnia can cause an increase in densities of smaller Cladocera such as Bosmina, together with copepods, which can avoid fish predation more effectively than Daphnia [24]. Towards the end of the culture period when small-bodied species (e.g. Bosmina and ultimately rotifers) increase in numbers, it is usually an indication that predation pressure by the fish is too great. The many fry had grown to fingerling sizes which were large enough to impose a higher predation on the zooplankton community. On the other hand the low levels of large zooplankton species and most nutritious species such as cladocerans could either be an indication that the refugia had low nutrients to allow a higher phytoplankton biomass to hold a sustain a better zooplankton community. The refugia were manure only once at the beginning of the culture. The refugia were surviving on the natural nutrient recycling which can be insufficient for a semi-intensive system of growing rice and fish in the same plot.

The refugia (paddy 2) with highest number of fingerlings harvested recorded the highest number of large sized phytoplankton, euglenoids and dinoflagellates. There was significant Pearson correction between fingerling number and euglenoids biomass $(x=0.92$ at $\mathrm{p}<0.000)$.
According to Eldridge et al. [11] there are direct relationships between fish ingestion rates, larval size, or fish larval density to prey density. As the culture season progresses, there is increasing fish predation pressure on large-bodied zooplankton populations. Large zooplankton feed on the large nutritious phytoplankton, therefore any reduction in the numbers of large zooplankton due to selective feeding by fingerlings, will result in increased numbers of large phytoplankton. The smaller-bodied phytoplankton species tend to appear towards the end of the culture period leading to an overall increase in small-bodied zooplankton species (e.g. Bosmina and ultimately rotifers) [29].

Not all fish species require the same size of prey at the onset of feeding. For instance, reciprocal cross hybrid striped bass have very small mouths that require them to consume small prey, such as rotifers and the early instar stages of cladocerans [23]. Small fish randomly select for zooplankton, although Brachionus, Keratella and Filinia (Rotifers) are mostly found in their stomachs. Crustaceans and their nauplii are generally avoided by small fish. According to Kaggwa et al. [30] Cyanobacteria, Chlorophyta and Bacillariophyta are the dominant algae in Oreochromis nilotocus gut content. Generally, planktivorous fish will preferentially remove the largest sizes of zooplankton [23] Therefore, ponds containing large-bodied zooplankton (yet, small enough for the fish to consume) should be more successful than ponds containing small-bodied zooplankton. The rice paddies which had the highest number of large zooplankton than ponds is highly recommended for raising tilapia fry for stocking in the rice-fish integrated systems tried out in East Africa. This reduces the costs of digging nursery and breeding ponds. The farmers instead use their part of the modified rice paddies to produce fingerlings for stocking on the rest of the rice field.

Fingerling harvested from the fish refugia with the higher water (paddy 2) recorded a larger size than harvested from other refugia. This was attributed to the condusive environment created by the stable water parameters column and higher plankton community. The fingerlings were not limited by the higher temperature and oxygen variations which are common in shallow waters. Fingerlings measuring 70-100 millimeters and longer achieve good survival rates and growth [3]. Fish should be stocked in environments suitable for their sustenance and growth. They should grow quickly by being highly efficient in utilizing natural food. Fish species that feed low on the food chain are preferred, but they should also offer good eating, economic value and potential for marketing, either locally or in remote markets [3]. Water quality properties were well within the acceptable ranges for aquaculture in both habitats.

Fry behaviour still seems to indicate reliance on natural food organisms during the first 3-4 weeks of culture. No evidence is available that fry actually consume prepared feeds added to the ponds during the initial weeks of culture, and it is assumed that initially added feed serves as a fertilizer. Therefore, the best fertilization protocol for catfish fry would be one that quickly establishes a phytoplankton bloom to prevent macrophyte growth and produces the greatest number of large zooplankton at the time of fry stocking. High concentrations of copepods, cladocerans and ostracods would be desirable from the time of stocking through about 5 weeks of production [10].

\section{Conclusion}

In the integrated rice/fish system trial, water parameters favored the phytoplankton community, mainly dominated by Chlorophyta, Euglenophyta and Cyanobacteria. This plankton community which nourished a high zooplankton which in turn supported tilapia fry to 
Citation: Ssanyu GA, Rasowo J, Auma E, Ndunguru M (2011) Evaluation of Plankton Community Structure in Fish Refugia Acting as Oreochromic niloticus Propagation and Nursery Units for Rice/Fish Trials, Uganda. J Aquac Res Development 2:116 doi:10.4172/2155-9546.1000116

grow to fingerling stage from the propagation trials in the fish refugia. The fish refugia offered better plankton community for fry nourishment than fish ponds. Therefore, the rice/fish integration system can rely on the fish refugia to propagate enough fingerlings for stocking in the rice paddies. Manuring paddies regularly and keep the water level high maintain condusive environments for fry to grow and this can lessen the reliance of small scale rice farmer on the unreliable government fry sources in the region.

\section{Acknowledgement}

The authors would like to thank the Swedish International Development Agency through the Lake Victoria Research (VicRes) for financial assistance to conduct this study. This research was carried out as part of the project on Developing Decentralized Rice Seed and Fish Fingerling Production Strategies in Farmers' Ricefields in the Lake Victoria Basin funded by SIDA/SAREC through the Lake Victoria Research Initiative (VicRes). We are also grateful for the institutional support provided by Moi, Kyambogo and Mzumbe Universities.

\section{References}

1. Osuigwe DI, Onuoha GC, Okocha PI (2007) Evaluation of rice-fish culture in south eastern Nigeria. Journal of Fisheries International 2: 118-121.

2. Halwart M, Gupta MV (2004) Culture of fish in rice fields. FAO and the WorldFish Center pp 83.

3. Vass KK, Shrivastava NP, Katiha PK, Das AK (2009) Enhancing fishery productivity in small reservoir in India. A Technical Manual. WorldFish Center Technical Manual No. 949. The WorldFish Center, Penang, Malaysia. pp. 9.

4. Li K (1988) Rice-fish culture in China. Aquaculture 71: 173-186.

5. Bambaradeniya CNB, Amerasinghe FP (2003) Biodiversity associated with the rice field agro-ecosystem in Asian countries: a brief review. International Water Management Institute. Colombo, Sri Lanka. Working Paper 63.

6. Halwart M (1994) Fish as biocontrol agents in rice: the potential of common carp Cyprinus carpio (L.) and Nile tilapia Oreochromis niloticus (L.). Tropical Agroecology. Published by Margraf Verlag, Weikersheim, Germany.

7. Fernando $\mathrm{CH}$ (1996) Ecology of rice fields and its bearing on fisheries and fish culture. In de Silva SS (Ed.) Perspectives in Asian fisheries pp 217-237.

8. Simon D, Benhamou JF (2009) Rice-fish farming in Guin'ee Foresti ere outcome of a rural development project. Field Actions Sci. Rep. 2: $49-56$.

9. Morris JE, Mischke CC (1999) Plankton management for fish culture ponds NCRAC Technical Bulletin \#114, NCRAC Publications Office, lowa State University, Ames, IA.

10. Mischke CC, Zimba PV (2004) Plankton community responses in earthen channel catfish nursery ponds under various fertilization regimes. Aquaculture 233: 219-235.

11. Eldridge MB, Whipple JA, Bowers DMJ, Jarvis BM (1981) Effects of food and feeding factors on laboratory-reared striped bass larvae. Trans Am Fish Soc 110: $111-120$.

12. Pennak RW (1989) Freshwater invertebrates of the United States: Protozoa to Mollusca. 3. ed. John Wiley \& Sons, Inc, New York, 628p.

13. Lampert W (1987) Feeding and nutrition in Daphnia. In Peters RH, de Bernard $\mathrm{R}$ (Eds) Daphnia. Memorie dell'Istituto Italiano di Idrobiologia 45: 143-192.

14. NEMA (2005) State of the Environment Report for Uganda 2004/2005. National Environment Management Agency, Government of Uganda, Kampala, pp 147.

15. Bourrelly P (1970) The Freshwater Algae. Tome III: Les algues bleus et rouges, Les Wetenschappelijke Mededelingen van de Koninklijke Nederlandse Natuurhistorische Ed. Boubee, Paris, pp 512

16. Coesel PM (1983) De Desmidiaceeen van Nederland, Bd. 2: Fam Closteriaceae. Stichting Uitgeverij Koninklijke Nederlandse Natuurhistorische Verening, Utrecht, $49 \mathrm{~S}$

17. John DM, Whitton BA, Brook AJ, (2002) The freshwater algal flora of the British

18. Isles: An identification guide to freshwater and terrestial algae. Cambridge University Press, Cambridge, United Kingdom, $702 \mathrm{~S}$.

19. Rasowo J, Auma E, Ssanyu G, Ndunguru M (2008) Does African catfish (Clarias gariepinus) affect rice in integrated rice-fish culture in Lake Victoria Basin, Kenya? African Journal of Environmental Science and Technology 2: 336-341.
20. Boyd CE (1982) Water Quality Parameters for Fish Culture. Elsevier Science Publishers, Amsterdam, The Netherlands pp 318.

21. Fernando $\mathrm{CH}$ (1993) Rice field ecology and fish culture: an overview. Hydrobiologia, 259: 91-113.

22. Miah MNI, Ali MH, Ahmed NU (1994) Mono and polyculture of Silver Barb (Puntius gonionotus) in deepwater of rice systems in Bangladesh. NAGA 17 26- 27.

23. Haroon AKY, Pittman KA, Blom G (1998) Diel feeding pattern and ration of two sizes of Tilapia, Oreochromis spp. in pond and paddy field. Asian Fish Sci 10: 281-301.

24. Bouvy M, Pagano M, Troussellier M (2001) Effects of a cyanobacterial bloom (Cylindrospermopsis raciborskii) on bacteria and zooplankton communities in Ingazeira reservoir (northeast Brazil). Aquat Microb Ecol 25: 215-227.

25. Stephen D, Moss B, Phillips G (1998) The relative importance of top-down and bottom-up control of phytoplankton in a shallow macrophyte dominated lake. Freshw Biol 39: 699-713.

26. Rocha O, Sendacz S, Matsumura-Tundisi T (1995) Composition, biomass and productivity of zooplankton in natural lakes and reservoirs of Brazil. In Tundis JG, Bicudo CEM, Matsumura-Tundisi T (Eds.) Limnology in Brazil. Brazilian Academy of Sciences and Brazilian Limnological Society, Rio de Janeiro, p. 151165.

27. Zaret TM (1980) Predation and freshwater communities. Yale University Press, New Haven, Connecticut. 187 p.

28. Gilbert JJ (1967) Asplancha and posterolaral spine production in Brachionus calyciflorus. Archives. Hydrobiologia 64: 1-62

29. Drenner RW, McComas SR (1980) The roles of zooplankter escape ability and fish size selectivity in the selective feeding and impact of planktivorous fish. Evolution and Ecology of Zooplankton Communities. Special Symposium, American Society of Limnology and Oceanography 3: 587-593.

30. Graves KG, Morrow JC (1988) Tube sampler for zooplankton. Progressive Fish Culturist 50:182-183

31. Kaggwa RC, van Dam AA, Balirwa JS, Kansiime F, Denny P (2009) Increasing fish production from wetlands at Lake Victoria, Uganda using organically manured seasonal wetland fish ponds. Wetlands Ecology and Management 17: 257-277. 